\title{
The analysis of assessment instruments in English teacher lesson plans at junior high school in Singaraja Bali
}

\author{
Desak Ketut Indriyani ${ }^{1}$, Luh Putu Artini ${ }^{2}$, Luh Diah Surya Adnyani ${ }^{3}$ \\ 1,2,3English Education, Foreign Language Department, Universitas Pendidikan Ganesha Singaraja, Indonesia \\ 11desakindriyani09@gmail.com, 2putu.artini@undiksha.ac.id, ${ }^{3}$ surya.adnyani@undiksha.ac.id \\ *) correspondence: desakindriyani09@gmail.com
}

\begin{abstract}
Education and Culture Ministry Regulation 81A Year 2013 has demanded teachers to use authentic assessment as a method of assessing students' competences which is applied in English teachers' lesson plans. This research aims to describe types of assessment instruments used in lesson plans, the relevancy between the assessments and indicators in the lesson plans, and the authenticity of assessment instruments used by English teachers as demanded by Curriculum 2013. The data were collected through document analysis of 20 English teachers' lesson plans from 4 Junior High Schools in Singaraja, Bali. The research model from Miles and Huberman (1984) was adopted in data analysis process. The instruments were derived and modified from principles of authentic assessment in Education and Culture Ministry Regulation 81A Year 2013. As the result, it was found that performance assessments and project assessment were used as the assessment types in the implementation of authentic assessment. The assessment instruments were relevant to the indicator of learning and the skills' aspects in assessment instruments used was authentic as demanded by Curriculum 2013.
\end{abstract}

Keywords: authentic assessment; assessment instrument; curriculum 2013

\section{INTRODUCTION}

Indonesian government has been implementing a new curriculum which accommodated the $21 \mathrm{st}$ century learning skills since 2013. This curriculum is called Curriculum 2013 as it was targeted to reach competencies and characters needed in reaching 21st century skills. Curriculum 2013 is functioned to prepare Indonesian citizens with both life skills as an individual and a citizen who is faithful to God, be productive, creative, innovative, effective as well as contributive to society, nation, and world civilization (Ministry of Education and Culture, 2013).

To reinforce the employment of Curriculum 2013, the teaching quality is a key to boost students' success on learning (Darling-Hammond, 1997). However, to have a good quality in teaching, teacher should prepare a lesson plan before teaching and learning are conducted. Education and Culture Ministry Regulation No. 81A (2013) stated that lesson plan is a syllabus-based learning plan developed in detail about a main material or main topic. A lesson plan covers school identity, subject, and class/semester, material, time, learning objective, basic competence, and indicator, learning material, learning method, media, instrument, learning process, and evaluation (Djuwairiah Ahmad, 2015). Based on the Circular Letter of Education and Culture Ministry No 14 Year 2019, the preparation of Lesson Plan was simplified from thirteen components into three components. These three components are the importance of learning, learning activities and assessment. Lesson Plan writing must be done effectively and efficiently. In term of number of sheets, this lesson plan was quite written on a piece of paper. 
The Curriculum 2013 has three aspects of assessment namely knowledge, skill, and attitude. Assessment is carried out comprehensively to continuously determine the development of students in developing their potential including spiritual attitude competencies, social attitudes, knowledge and skills. According to Education and Culture Ministry Regulation 81A Year 2013 about the implementation of Curriculum 2013, the assessment applied was authentic assessment. Authentic assessment is a global assessment process to assess critical thoughts, motivation or actions. In this assessment, students are expected to think critically, analyze information, obtain new ideas, communicate, collaborate, solve problems, and conclude the information obtained. In this authentic assessment, students' competencies are assessed, whether knowledge, skills, or attitude, or a combination of those three (Gulikers, et al, 2004). Marhaeni \& Artini (2014) explained that Curriculum 2013 was compatible with authentic assessment. It was because authentic assessment measured the process and product of learning and developed four basic competencies namely social attitude, religious competency, knowledge and skill. In addition, authentic assessment also built behavior to think logically, objectively, critically and creatively.

There are four types of authentic assessment that should be implemented at school based on Curriculum 2013. Those are self-, performance, project, and portfolio assessment. The Curriculum 2013 required English teachers to apply authentic assessment as a method of educational measurement. Authentic assessment was an evaluation process involving multiple forms of student's performance on instructionally-classroom activities. This assessment contributed to the development of effective classroom measurement. It encouraged students to be more active and to help teachers reflected on their teaching and improved the instruction.

In line with the implementation of authentic assessment, English teachers realized the use of authentic assessment instruments in learning and teaching process was necessary. As required in Curriculum 2013, the instruments assessment designed by the teacher should be authentic. The assessment covered the knowledge, attitude and skills during teaching and learning process. Teachers planned an appropriate assessment instrument based on the competencies that had to be achieved and applied in real-life by the students. The teachers had been facilitated throughout training or workshop and documents of Curriculum 2013 module as planning preparation. Accordance to this point, this current research was important to be conducted since the research focused on analyzing the assessment instruments for teacher had not much been done. As the compulsory subject, English subject required students to be able to cover the four basic skills namely reading, writing, speaking and listening. In order to cover those basic skills, teachers must prepare the assessment instrument which was relevant and authentic as required by Curriculum 2013 since those affected the success of Curriculum 2013 implementation. It was because the assessment was used to monitor the process and improvement of students whether the students reached the basic competence or not. Besides, the assessment was also a feedback for the students to evaluate the learning plan and process (Education and Culture Ministry Regulation No. 23 Year 2006 about the standard of assessment). The key of Curriculum 2013 implementation success was the scoring system done by the teacher (Alimuddin, 2014) whereas, teachers were confused in assessing students, especially in the way of evaluation because there were many indicators that must be accommodated. Besides, curriculum revisions made teachers confused in applying the Curriculum 2013, it was caused by activities that must be done in the learning process and assessment (Armadeni, Rezi \& Arief, 2019). Varied opinion in assessing the students in Curriculum 2013 caused confusion for teachers in the field (Allimuddin, 2014). Teachers possessed knowledge about the importance of authentic assessment to be instrumented, yet it was still found that teachers needed help in providing assessment instruments in the classroom (Marhaeni\&Artini, 2014). Therefore, the implementation of authentic assessment is quite challenging for English teacher (Rukmini, 2017).

\section{METHODS}

Since the present research concerned with the assessment instrument used by English teachers' lesson plans, a descriptive qualitative study design was employed. This research was aimed to describe types 
of assessment instruments used in lesson plans, the relevancy between the assessments and indicators in the lesson plans, and the authenticity of assessment instruments used by English teachers as demanded by Curriculum 2013.

This research used lesson plans to obtain the data. The lesson plans used has been permitted by the school headmasters, the curriculum coordinators and English teachers which were all 20 lesson plans collected from 4 state junior high schools as the representative of 8 state junior high schools in Singaraja. The analysis technique was done by involving table analysis to obtain the data needed for the current research.

The data were analyzed by using four steps of Miles and Hubberman's (1984) analysis model, namely data collection, data reduction, data display and conclusion. The assessment instruments used in lesson plans were analyzed and the data were compiled to be confirmed and justified. After the data were obtained, it was processed and then continued by organizing, identifying and also categorizing the important items remained. The following step was displaying the data analyzed. It was presented and interpreted using supported theories in order to make the readers easier in understanding the data before the conclusion was drawn.

In order to prove data validity and reliability, decrease investigator bias and provide multiple perspective, this study used the triangulation of theory, source, investigator and methodological. The triangulations in this current research have been done by comparing the data obtained from lesson plans written by the English teachers with the theories and data analysis using several tables and asking other experts involved in analyzing the data. Some irrelevant data was eliminated to meet the objective of this research which answered the research question.

\section{RESULTS AND DISCUSSION}

Based on the analysis of assessment instrument types used in English teachers' lesson plans at Junior High School in Singaraja,Bali, it was found that the performance and project assessment were used as the types of authentic assessment in Curriculum 2013. As mentioned in Education and Cultural Ministry Regulation No 23 Year 2013, the assessment instruments used should be authentic assessment as it implemented skills aspect. The teachers can use performance, project and portfolio to assess students' practice test. The analysis revealed 4 lesson plans that were not categorized as the types of authentic assessment as demanded in Curriculum 2013, those were; Lesson plan 2, Lesson plan 3, Lesson plan 7, Lesson plan 15. In Lesson plan 2, the learning topics were capability and willingness expressions. The assessment instrument attached by English teacher required students to make a dialogue based on the content. The unclear instruction of assessment instrument caused this assessment instrument was not categorized as the types of authentic assessment. In Lesson plan 3, the assessment instrument required students to create a greeting card creatively, however, the teacher just assessed the product of greeting card. In Lesson plan 7, the assessment instrument required students to make a dialogue based on the learning topic. It could not be categorized as types of authentic assessment because of the unclear instruction of assessment, meanwhile in Lesson plan 15 the assessment instrument required students to create greeting card creatively. The product was assessed in this lesson plan without assessing the process of student. Thus, the fourth lesson plans were could not be identified the type of authentic assessment.

The result analysis of relevancy between the assessment instruments used by English teacher lesson plan with the learning indicator found that the assessment instruments used in English teacher lesson plans were relevant to the learning indicator. In Curriculum 2013, there were three aspects that should be covered in assessment, namely knowledge, attitude and skills. This part figured out the compatibility the assessment instruments used in knowledge aspect and skills aspect. Those twenty lesson plans that have been analyzed found that the knowledge aspect was covered by multiple choice test, fill in the blank of the sentences, completing the dialogue, and short essay. The multiple choice was used in Lesson plan with 4 lesson plans used fill in the blank of sentences, completing the dialogue and 2 other lesson plans was identified used short essay. However, the skills aspect covered practice 
assessment in which students demonstrated current competency by performance and project. The assessment instruments used by students were to make dialogue based on the context and performance it, demonstrate storytelling, construct dialogues by given situation and practice them in front of the class. Besides, the assessment instruments attached by English teacher required students to make greeting card, write describing people, and write the unforgettable moment. The process and product were assessed by teacher.

The authenticity result analysis of the assessment instruments used in English teacher lesson plans found that the assessment instruments used was authentic as demanded in Curriculum 2013. There were 60 assessment instruments attached by English teacher in lesson plans and 24 assessment instruments fit into the characteristics of authentic assessment. As the assessment used by teachers should be authentic especially in skills aspects and in knowledge aspect in Education and Cultural Ministry Regulation No 23 Year 2016, 24 assessment instruments have used authentic assessment in skills aspects. The assessment instruments attached by English teacher required students to do practice or presentation in a field study by performance and project.

It was found that performance assessment and project assessment were used as types of authentic assessment. In accordance to twenty lesson plans that have been analyzed, the assessments attached by English teacher in skills aspect have employed basic skills of English language skills. The students were asked to arrange picture story and tell the story to their friend in front of the class. In the other assessments, students were asked to perform the dialogue that they have arranged, construct the dialogue by situation given and perform it in front the class. Thus, performance is a certain activity that required students to practice or present in a field study (Wiggins, 1998). The teachers tended to use performance assessment because it was an assessment that reflected good instructional activities that were often taught to be more engaging for students Linn and Burton (1994). Besides, the design of performance assessment was to develop individual skills (Meisel, et al 2010). Thus, assessing students' ability in knowledge and skills mastery in any situations and real contexts were the performance test's main goals (Wiggins in L.Merickel (1998:1). The next analysis result was project assessment type used in English teacher lesson plans, however, the number of assessment using project assessment type was not as many as the performance assessment type. The assessment attached by English teachers in their lesson plans asked students to make greeting card, write describing people, and write the unforgettable moment by students. The theory from Wiggins (1998) stated that describing people in written text indicated students' experience and it enabled students to improve the related skills or knowledge. A project assessment was a learning assignment which included planning activity, process and report in the form of written or oral in a period (Education and Culture Ministerial Regulation No 23 Year 2016, standard assessment of education). The teacher tended to use project assessment because it can improve students' problem-solving skill and encourage students to develop their communication skill (Daryanto, 2014:26). Hence, the project assessment trained students to be more independent in solving problems (Susanto, 2013:195).

The assessment instruments used in lesson plans have fulfilled the requirement of Education and Cultural Ministerial Regulation No 23 Year 2016 in which assessment instruments included three aspects namely: attitude, skills and knowledge. Those twenty lesson plans have been analyzed found that the knowledge aspect covered by multiple choice test, fill in the blank of the sentences, completing the dialogue, and short essay. The multiple choice used in Lesson plan 4 covered 4 lesson plans which used fill in the blank of sentences, completing the dialogue and 2 lesson plans identified used short essay. Meanwhile, skills aspect was covered by practicing assessment in which students demonstrate current competency by Performance and Project. As mentioned in Education and Cultural Ministerial Regulation No 23 Year 2016 about the principles of standard assessments, the assessment should be systematic which means in assessing students to stick to the planning and steps by following the agreed procedure is important. Besides, the assessment should be criteria-based which means that the assessment should be relevant to competency-achievement determined. Hence, assessment should measure what is formulated in the objectives about what and how well students should demonstrate. Besides, Paramartha\&Pratiwi (2017) mentioned incompatibility between basic competence and 
indicator as to the basis of the assessment application as one out of three of their research findings. Basic competence is as important as learning indicator which creates the quality of teaching and learning process. Therefore, the twenty lesson plans have been relevant both in learning indicators and assessment used as demanded by Curriculum 2013 by which the focus of the research was skills and knowledge aspects.

The authenticity of assessment instruments used in English teacher lesson plans it found that the assessment instruments used was authentic as demanded in Curriculum 2013.There were 24 assessment instruments fit into the characteristics of authentic assessment. As mentioned in Education and Cultural Ministry Regulation No 23 Year 2016, the assessment used by teacher should be authentic especially in skills aspects and in knowledge aspect the assessment instrument can used traditional test. In line with this point, those 24 assessment instruments used authentic assessment in skills aspects. The assessment instruments attached by English teacher require students do practice or presenting in a field study by performance and project. The authentic assessment measures the learning aspects in which performance aspects and product aspects were covered. It is because of the performance and product as the reflection of students' progress which were objective and real (Kunandar, 2013:38). The assessment is authentic if there is consistency between the assessment and the real-world application for which the learner is being prepared (Tanner, 1997). Based on the analysis result, the use of authentic assessment in skills aspect has been proven authentic and assessment in knowledge aspect was still dominated by traditional test. In Line with research by Paramartha \& Pratiwi (2017) that one in-authenticity of the assessment instruments used by teachers in the class was due to the instruments used in measuring reading and listening were only conventional text such as multiple choices, false-true questions, fill in the blanks, and essay. It did not meet the requirements of Curriculum 2013 about authentic assessment. Another research by Rukmini (2017) revealed that the English teachers of the school had implemented an authentic assessment to measure students' English productive skills but the implementation has not been conducted properly yet. It was affected by the important use of authentic assessment in knowledge either aspect or skill aspects. Students who did practice or presentation contextually means that the assessment used was close to the actual context and the related skills or knowledge were used as well (Wiggins, 1998). However, this research which was based on Education and Cultural Ministerial Regulation No 23 Year 2016 about standard assessment allowed knowledge aspect to keep employing traditional assessment.

\section{CONCLUSION}

Based on the result of analysis, the assessments instruments used performance and project assessment types as authentic assessment. Assessment instruments and indicators of lesson plan showed that the lesson plans were relevant to the indicators of lesson plans. The authenticity of assessment instruments used in lesson plans used by the English teachers were authentic. Based on the results of analysis, it showed that the assessments instruments used in lesson plan written by English teachers had to be supported by the authentic assessment in Curriculum 2013. It was also showed that teachers realized the importance of authentic assessment which has been proven by designing the assessment types and project assessment. Assessment instruments and indicators of lesson plans showed that the lesson plans were relevant to the indicators of lesson plan. The authenticity of assessment instruments used in lesson plans used by the English teachers were authentic in skills aspect. It also showed that teachers realized the importance of authentic assessment has been proven by designing the relevant instruments related to the indicator of lesson plans.

\section{REFERENCES}

Asmawati, E. S., Rosidin, U., \& Abdurrahman. (2018). The Development of Asessment Instrumen Towards the Students' Critical Thinking Ability on the High School Physics Lesson wirh the Creative Problem Solving Model. International journal of advanced research, 90-98. 
Borich, G. D. (2007). Effective teaching methods, Unit and Lesson Planning, Six Edition. Ohio: Pearson Merrill Prentice Hall.

Brown, H. D. (2004). Language Assessment: Principles and Classroom Practices. San Francisco: Pearson Education.

Gulikers, J.T.M., Bastiaens, T.J., \& Kirschner, P.A. (2004). Educational Technology Research and Development. "A Five-Dimensional Framework for Authentic Assessment". Vol. 52, No. 3, 67- 86.

Creswell, J. W. (2012). Planning, Conducting, and Evaluating Quantitative and Qualitative Research: Fourth Edition. Pearson: University of Nebraska-Lincoln.

Harmer, J. (2007). The Practice of English Language Teaching 4th Edition. Harlow: England Pearson Education.

Kunandar. 2013. Penilaian Autentik (Penilaian Hasil Belajar Peserta Didik Berdasarkan Kurikulum 2013). Jakarta: (Sulistyani, 2019) Rajawali Press.

Khoriah, Jalmo, T., \& Abdurrahman. (2018). Development of Assessment Instruments Higher Order Thinking Skills of Science Subjects for Student Grade eight Junior High School. The online journal of new horizons in education, 19-29.

Lumadi, M.W. (2013). "Challenges Besetting Teachers in Classroom Assessment: An Exploratory Perspective". Journal of Social Science, 211.

Marhaeni, A., \& Artini, L. P. (2015). Asesmen Autentik dan Pendidikan Bermakna : Implementasi Kurikulum 2013. Jurnal Pendidikan Indonesia, 500-511.

Marhaeni, A., \& Kusuma, I. P. (2017). Analisis Implementasi Asesmen Autentik pada Pembelajaran Bahasa Inggris dalam Implementasi Kurikulum 2013 di SMA di Bali. Seminar Nasional Riset Inovatif, 555-561.

Nesari, A.J., \& Heidari, M. (2014). The Important Role of Lesson Plan on Educational Achievement of Iranian EFL Teachers' Attitudes. International Journal of Foreign Language Teacbing \& Research, $25-31$.

Peraturan Menteri Pendidikan dan Kebudayaan. (2013). Curriculum Development 2013. Jakarta, Indonesia: Author.

Peraturan Menteri Pendidikan dan Kebudayaan. (2016). Standard Assessment in Education. Jakarta, Indonesia: Author.

Peraturan Menteri Pendidikan dan Kebudayaan. (2016). Standard Process of Primary and Secondary Education. Jakarta, Indonesia: Author

Peraturan Menteri Pendidikan dan Kebudayaan. (2018). Structure of Curriculum 2013 SMP-MTS. Jakarta, Indonesia: Author.

Rukmini, D., \& Eko Saputri, L.A.D. (2017). The Authentic Assessment to Measure Students' English Productive Skills Based On 2013 Curriculum. Indonesian Journal of Applied Linguistics, Vol. 7 No. 2, $263-273$.

Sulistyani, U.N. (2019). 2013 Curriculum Evaluation: a Comparison to Language Curriculum Design and 21stCentury Learning Skills. Jurnal Pendidiksn Humaniora, Vol. 7 No. 4, 157-165

Safitri, I.D., Sumardi, \& Supriyani, S. (2018). Learning Strategies Used by The Students in EFL Classroom. Humaniora Vol. 9 No. 3, 291-303.

Sesiorina, S. (2014). The Analysis of Teachers' Lesson Plan in Implementing Theme-Based Instruction for Teaching English to Young Learners. Journal of English and Education, 84 - 95.

Tosuncuoglu, I. (2018). Importance of Assessment in ELT. Journal of Education and Training Studies, 163 $-167$. 